\title{
The U.S.-China Technological War
}

\section{Digital Technologies as a New Factor of World Politics?}

\section{Ivan V. Danilin}

\author{
Ivan V. Danilin \\ The Primakov Institute of World Economy and International Relations (IMEM0), \\ Moscow, Russia \\ Head of Science and Innovation Department \\ ORCID: 0000-0002-4251-1998, \\ ResearcherID: L-4388-2017 \\ SPIN: $1155-9148$ \\ E-mail: danilin.iv@imemo.ru \\ Tel.: +7 4991288796 \\ Address: 23 Profsoyuznaya Str., Moscow 117997, Russia
}

This article is part of the project "Post-Crisis World Order: Challenges and Technologies,

Competition and Cooperation" carried out with support from the RF Ministry of Science and Higher Education (Agreement \# 075-15-2020-783).

DOI: 10.31278/1810-6374-2021-19-4-78-96

\begin{abstract}
The technological war, or Tech War, as part of the geopolitical conflict between the United States and China raises a range of questions for researchers, the most important one being the role of digital technologies and markets in international relations and world politics. The article studies the motives and objectives of the Tech War and its long-term effects using available academic literature on sanctions and research data on the digital economy and high-tech markets, including the political aspects of the U.S.-China rivalry. Analogues from the Cold War and other conflicts suggest that the economic purpose of the Tech War is to limit China's capacity in
\end{abstract}


the long term. However, the new realities transform both the instruments and goals of the traditional superpowers' economic withstanding. The importance of information and communication technologies (ICT) and the rise of the digital economy have made traditional geopolitical and market (commercial) dimensions of the conflict intertwined with high technology seen as a strategic resource and a separate area of conflict. As for the role of digital technology in world politics, a reverse process is observed: its importance is growing due to the traditional (geo)political factors, including securitization of the digital sphere, enhanced by the narratives of new technological revolutions. These factors increase the intensity of the Tech War since competition in high-tech markets is perceived as a zero-sum game. However, in the long term, the globalized, highly internationalized nature of digital markets and technologies may lead to the normalization of global processes and world politics.

Keywords: U.S., China, technological war, digital technologies, global hightech competition, geopolitics.

tarting from 2018-2019, the United States has been pushing ahead with technological sanctions against leading Chinese companies and China itself, restricting bilateral scientific and technological relations. Such measures apply to the import of Chinese products, venture capital investment, access of Chinese companies to U.S. stock markets, and interaction between research centers (Mascitelli and Chung, 2019; Sun, 2019; Leksyutina, 2020; Danilin, 2020; Wu, 2020). The focus is on information and communication-digitaltechnologies as the most significant factor of modern development. Moreover, due to the extraterritorial nature of U.S. sanctions and dialogue with allies, many restrictions are turning global (specifically those on 5G, microelectronics, etc.). These processes, initiated following the start of the trade war (Steinbock, 2018; Salitsky and Semenova, 2019; Sun, 2019; Leksyutina, 2020; Afontsev, 2020) and by analogy with it, have been called 'technological war,' or 'Tech War.'

This special battlefield between the two superpowers needs to be studied most seriously. On the one hand, just like the trade war (Afontsev, 2020, p. 193-194), the technological conflict largely came as 
a surprise, heralding a departure from the previous logic of building open high-tech markets and global value chains. It is important to note that the scale and depth of the conflict clearly go beyond the "usual" technological bounds of the post-bipolar period (Kaempfer and Lowenberg, 2007; Hufbauer et al., 2009; Smeets, 2018; Hufbauer and Jung, 2020) and look very much like another Cold War.

On the other hand, the Tech War between the United States and China raises a much more important question about the role of digital technologies in modern world politics and international relations. The discussion on how ICT significantly change the parameters of a state's might and power, as well as the aggregate capacity of states has been going on for quite a while, just like the debate on a greater role of the civilian technological sector in international relations and foreign policy (Simon, 1996; Ross, 2011; Kissinger, 2014; Cartwright, 2020; Wu, 2020; Raska, 2021). But can we say that modern digital solutions and, especially, such technologies as 5G, artificial intelligence or quantum systems form some new dimension of international political and geopolitical processes? Many authors point to a new level of challenges and threats, and some even claim that due to the information manipulations and other capabilities digital corporations are transformed into new instruments of power projection, while commercial digital technologies appear to be more and more weaponized (Dorfman, 2020; Cartwright, 2020; Oates, 2020).

An analysis of the Tech War could help us understand whether we are really witnessing a transformation of ICT's role in global politics, or we are dealing with some traditional phenomena reengineered for the new realities.

To answer this question, it seems appropriate to address the theories of economic sanctions and, more broadly, of economic confrontations between superpowers, with special attention paid to the research on securitization and political aspects of high-tech competition (including the ideas of neo-techno nationalism). Since the initiator and the impelling force of the Tech War is the United States (China painstakingly depoliticizes its international technological relations), this paper focuses primarily on U.S. policies and strategies. 


\section{TECHNOLOGICAL WAR AS PART OF THE GREAT-POWER CONFLICT}

Presumably, the first step towards understanding the essence of the technological war and the role of digital technologies in contemporary international relations is to analyze the causes and objectives of the U.S.-China confrontation in the ICT area.

The rationale for the Tech War has been formalized in U.S. official documents (see, for example, U.S. Department of Defense, 2020; U.S. Department of State, 2020, pp. 4-19, 24-26). Apart from the prevention of risks to global democracy and sanctions for the alleged suppression of ethnic minorities (which rather reinforce the focal points of U.S. policies), three key groups of causes and objectives can be distinguished.

Firstly, there are quite traditional measures (Mastanduno, 1985; Huffbauer et al., 2009) aimed at containing the rival power by preventing the export and other types of critical defense and dual technology transfer from the United States and its allied and partner nations. Incidentally, this approach has been invariably present in U.S. policies towards China. Here the focus is on the Chinese commercial ICT sector, which since 2018 is also reinforced by China's civil-military fusion strategy. The latter implies tighter interaction between Chinese defense-related organizations and private high-tech companies as sources of cutting-edge technologies (Manuel and Hicks, 2020; U.S. Department of Defense, 2020, pp. 16-22, 142).

This rationale corresponds with the second goal-reducing vulnerability of the United States, its allies and partners to nextgeneration cyber threats that are attributed to Chinese digital technologies (Leksyutina, 2020; U.S. Department of State, 2020, pp. 11-13, 23-24; Dorfman, 2020; Smith and Brown, 2021).

Finally, a separate goal of the Tech War is limiting China's "unfair" trade and economic practices (Atkinson and Ezell, 2012; Nakayama 2012; Shim and Shin 2016; Gewirtz, 2019; Manning, 2019; Gewirtz, 2019; Qin, 2019; Kim et al. 2020; Capri, 2020; U.S. Department of State, 2020). Washington accuses Beijing of forcing Western companies to transfer technologies, stealing intellectual property, providing exclusive support for "national champion" companies, and using 
other non-market measures to boost economic development. These accusations are not new and have already caused controversies in the past (Johnson-Freese and Erickson, 2006; Atkinson and Ezell, 2012; Shim and Shin, 2016), but since the mid-2010s, amid the boom of the Chinese high-tech sector, they have become critical. China's new innovative potential and supportive policies not only threaten U.S. economic competitiveness, but also pose risks to American leadership and technological sovereignty.

However, for all the importance of these motives and goals and the general context of the U.S.-China conflict, the available literature on sanctions clearly indicates that we are witnessing a much more important phenomenon. Using the classification of sanctions proposed by M. Mastandano with regard to the Cold War, we can define this phenomenon as 'economic war' (Mastanduno, 1985, pp. 506-514). Its aim is to limit the aggregate capacity of the rival power and its growth in the long term (Mastanduno, 1985; Kaempfer and Lowenberg, 2007; Hufbauer, et al., 2009; Smeets, 2018). In the case of the Tech War, sanctions and other measures are expected to increase the costs of China's innovative development. This, in turn, is considered a critical solution to eliminate the risk of China's emerging as the United States' opponent with comparable or equal economic and military potential. It is important to note that many experts and the Chinese elites themselves interpret the Tech War precisely this way (Segal, 2019; Gewirtz, 2019; Leksyutina, 2020; Wu, 2020; Riecke, 2020).

This strategy is closely linked to the specifics of both the Chinese and global economy, and current technological trends. In particular, the emphasis on ICT is logical, considering the enormous importance of digital technologies for the growth of China's GDP (including export revenues and economic effects of digitalization on its basic industries) as well as for the development of its National Innovation System (UNCTAD, 2019; OECD, 2020). So is the focus on high-tech digital corporations and startups as the key actors in China's digitalization and innovative transformation (Steinbock, 2018; Sun, 2019).

These and other factors support the idea of the growing importance of digital technologies and, more broadly, of high-tech markets in 
international relations (Cafruny, 2019; Wu, 2020). However, the question arises: To what extent are ICT changing global politics?

What we see in the Tech War can partly be explained by some very traditional theoretical considerations. Firstly, this relates to the vision of commercial digital technologies as a new strategic resource in the race of superpowers, and secondly, as an important factor of their aggregate capacity growth (Ding and Defoe, 2021). These phenomena and interpretations are not new and have many historical parallels, from space technologies (in the U.S.-USSR "race" and even in the U.S.-EU and U.S.-China relations) to U.S.-Japan competition in the 1980s and 1990s in the electronics markets (Simon, 1996; Johnson-Freese and Erickson, 2006; European Union, 2019; Miller, 2019; Hobbs, 2020). However, it seems that the current conflict has affected the understanding of digital technologies as a new strategic resource and the attitude of elites towards the digital high-tech sector and markets.

\section{DIGITAL TECHNOLOGY AS A NEW FACTOR OF INTERNATIONAL RELATIONS}

The most important change brought about by the Tech War relates to the evolution of the phenomenon of economic war.

Today the concept of 'strategic resource' is not only interpreted in a broader way, but also changes approaches towards how the technological dimension of economic war is implemented. This relates to the shift of emphasis from traditional restrictions on the transfer of critical or dual-use technologies to a broader policy focus, and to prevention of Chinese high-tech trade and investment expansion (as part of the so-called neo-techno nationalist policies (Nakayama 2012; Shim and Shin 2016; Manning, 2019; Gewirtz, 2019; Kim et al., 2020; Capri, 2020)). Also, leadership in the global commercial high-tech markets is now perceived as an important factor in building a state's aggregate capacity, while market competition is obviously seen as a new space for geopolitical contentions and a factor of structural power.

The nature of these changes is well explained by the latest economic developments. 
In recent decades, the role of China and Chinese companies in the global ICT production and export has grown rapidly, reaching about $40 \%$ (in value-added terms) by the end of the 2010s (UNCTAD, 2019, pp. 51-58, 74-75; National Science Board, 2020, 41-44; The World Bank, 2021). Yet China remains highly dependent on the import of the most technologically advanced solutions-from electronic components and services for the manufacturing of high-performance chips to software (UNCTAD, 2019, 54; Lapedus, 2019; Grimes and Du, 2020; Congressional Research Service, 2020; Danilin, 2020). U.S. companies remain the key actors or ultimate technology and IP holders in these segments. For example, the U.S. still accounts for $47 \%$ of the semiconductor market (China only $6 \%$ ), including over $61 \%$ of logic chip production (China 9\%); 63\% of the analog semiconductor systems market (China's share is less than 5\%); and $40 \%$ of the equipment for semiconductor production (China is under 10\%) (Semiconductor Industry Association, 2020; Congressional Research Service, 2020). Also, U.S. intellectual property is present in all key industry solutions, which determines the effectiveness of U.S. extraterritorial sanctions that blocked the interaction of Chinese corporations with the leading providers of manufacturing systems in the field of microelectronics (ASML), chips and services for their contract manufacturing (TSMC, Samsung, Flex, etc.), and with other technological companies.

However, in the 2010s the rapid growth of Chinese companies and state support for the emerging digital technologies changed the situation. Competitive pressure on U.S. corporations increased so that the revision of the global value chains architecture in the electronics sector began to look a realistic possibility. In addition, the rise of the Chinese Internet sector as a new high-tech actor made the economic challenge even more viable. Importantly, this process took place during a new wave of digitalization expected to form new giant markets and produce significant effects on the global economy (UNCTAD, 2019; National Science Board, 2020, 41-44; OECD, 2020). Amid accusations against China of "unfair trade practices" this caused rising concern in the United States, which is well illustrated by the debate over the "Made in China 2025” program (Laskai, 2018; U.S. Congress, 2019; Cafruny, 
2019, pp. 118-119; Wey, 2019; Davis and Wei, 2019; Cory and Atkinson, 2020; Ding and Dafoe, 2021).

Economic (as well as defense) leadership was at stake. Since breakthrough digital technologies are currently developed primarily by private companies and globalization of their operations is an important factor of their success (incomes from trade, access to world talents, technological and production resources, etc.), geopolitical conflicts and trade wars begin to converge.

The interconnection between trade and geopolitics manifests itself even in international political initiatives. Quite illustrative in this respect are the U.S. Clean [Telecommunications] Network Initiative, the U.S.-EU Trade and Technology Council, as well as other U.S. initiatives in the dialogue with Europe, India and other partners to limit the penetration of Chinese digital standards into "democratic countries" (U.S. Congress, 2019; Cafruny, 2019; Danilin, 2020; Fidler, 2020; Wu, 2020; Riecke, 2020; Triolo, 2020, pp. 13-14, 18-20; Smith and Brown, 2021, p. 254). Efforts to prevent cyber risks and reduce China's economic influence are augmented by the struggle for control of standards as a factor of asymmetric trade advantages, as well as traditional protectionism. In turn, China's Digital Silk Road initiative, which previously had a mostly economic and neo-techno nationalist dimension (Shen, 2018), in the new realm seems to demonstrate a more distinct international political edge.

Historically, the situation is quite specific, if not unprecedented. The Soviet Union explored the possibility of exporting consumer electronics (Morita, 2014, pp. 154-156). But Soviet foreign economic activity was radically different from China's neo-techno nationalist policy and did not regard the export of civilian tech products as a major factor of development or as an instrument of achieving geopolitical goals (Khanin, 2008, pp. 235-242, 476-486). High-tech markets did not play any role in other systemic international conflicts involving the United States, including confrontation (until the end of the 1970s) with China, as well as with Iran, North Korea, and Russia in the postbipolar period (Huffbauer et al., 2009; Rogov, 2016). On the contrary, trade and economic conflicts, including those in the high-tech field, 
were previously almost devoid of geopolitical motives. The ongoing U.S.-China technological war is often seen as an analogy of the struggle between the United States and Japan over the electronics markets in the 1970-1990s (Irwin, 1996; pp. 127-167; Cafruny, 2019; Miller, 2019; Ding and Dafoe, 2021; Afontsev, 2020, pp. 193-194). But the latter one was much smaller in scale. And what is more important, unlike modern China, Japan had no international ambitions that would run counter to the U.S. interests. The discussions about the emergence of Japan as an independent global center of power in the 1980s and the 1990s were hypothetical, if not speculative (Vogel, 1989; Ishihara, 1991).

However, as soon as we recognize the great importance of commercial ICT for the aggregate capacity of states and, consequently, the growing importance of global high-tech markets for world politics, a new question comes to the forefront: To what extent does the digital high-tech sector determine the specifics of technological war and other international and political processes in this area?

\section{SECURITIZATION AS A DRIVER OF GEOPOLITICAL TRANSFORMATION OF DIGITAL HIGH TECH}

Oddly enough, the digital Tech War is not the ideal solution to the challenge of U.S.-China technological competition.

In the short term, U.S. sanctions have a visible negative impact on individual companies such as Huawei. The general picture is more complicated. The growth of Chinese ICT exports has slowed down, but not dramatically (from $10.16 \%$ in 2017 to $5.78 \%$ in 2020). The same is true of the Chinese share in the U.S. ICT imports (down from $50 \%$ to 43\%) (UNCTAD, 2021). However, China's ICT production and trade still grows, and so does China's share in global exports (from $42.06 \%$ to $43.37 \%$ ). Moreover, China has initiated new vigorous R\&D efforts, investments in startups and high-tech manufacturing. However costly this policy has turned out to be, it has clearly yielded certain positive results. Also, the U.S. pressure has not changed Beijing's position on the most important international issues or on the expansion of $5 \mathrm{G}$ and other digital solutions, including those within the framework of the Digital Silk Road project. 
Furthermore, even in the long term, when the main results of the Tech War are expected to manifest themselves, its effectiveness remains questionable. A full-scale technological blockade of China is impossible theoretically and practically (Mastanduno, 1985; Kaempfer and Lowenberg, 2007; Hufbauer et al., 2009, pp. 65-124, 158-160; Smeets, 2018, pp. 5-6; Danilin, 2020). Moreover, some compensatory strategies are possible, especially since changes in the aggregate capacity are marked by great inertia (Brooks and Wohlforth, 2016; Istomin, 2020). Nor should one ignore the enormous importance of non-technological factors such as the effectiveness of China's research policies, import substitution, and institutional reform. In other words, sanctions and other restrictions may not necessarily upset the quality of China's economic growth in the future.

Moreover, as American experts rightly point out, sanctions do not solve the United States' main task, namely, they do not increase its potential in competition with China (Gewirtz, 2019; Manuel and Hicks, 2020). Instead, they pose real risks to the normal development of the digital sector and ICT markets, which have historically kept the focus on global trade, open innovation, and the growth of international specialization and cooperation. This, in turn, may entail adverse effects on the U.S. economy itself.

The most adequate explanation for all these considerations is that the driving force behind the "war" is not so much the special features of digital high tech, as very traditional securitization of emerging digital technologies and global digital competition.

The specific nature of digital technology provides the widest opportunities for its securitization (Hansen and Nissenbaum, 2009; Lacy, 2018). This effect is enforced by two important features of the U.S.-China conflict. Firstly, it is the abovementioned vision of emerging digital technologies as a strategic resource. Secondly, one should take into account the narratives of technological revolutions, for example, the concepts of the Fourth Industrial Revolution, global changes under the influence of artificial intelligence, etc. (Brynjolfsson and McAfee, 2016; Rifkin, 2014; Schwab, 2017). The popularity of these ideas should be attributed to a variety of factors, including specific domestic social 
and economic agendas of the United States and China. In the United States, for example, the fear of de-industrialization, unemployment, and loss of economic and innovation leadership steers interest to the emerging "revolutionary" technologies. In China, it is the ideology of "catching up with and overtaking" the West (ganchao), as well as the need to ensure sustainable economic growth as a factor of social and political stability (Atkinson and Ezell, 2012; Gewirtz, 2019). The problem with the concepts of "revolutions" is that when they are actualized in the geopolitical discussion, the elites begin to view digital development as a non-cooperative game. Vladimir Putin expressed this perception of the elites very accurately in his speech on artificial intelligence. He said that the leader in the AI race would become the "master of the world" (TASS, 2017).

In addition, the very logic of technological war reinforces the trend towards securitization of both digital technologies and ICT markets. At the level of narratives, dominant telecommunication standards, emerging technologies, and other components of hightech confrontation are already described by the expert community and the elites in terms that are quite close to the categories of institutional and structural power (Barnett and Duvall, 2005; Gwynn 2019). However specific, similar considerations are clearly present in China, which, along with protectionism, has determined its efforts to prevent the penetration of U.S. Internet corporations into the Chinese market.

In other words, technological war is not an inevitable consequence of the impact of digital high tech on international relations. There is an overassessment of the challenges and opportunities associated with emerging technologies-in full accordance with the defense and political processes described by the concept of strategic uncertainty (Istomin, 2020). We can even say that ideas of new "revolutions" in the realm of global competition and the rise of new centers of power (including high-tech ones) bring American and other global elites into the digital "Thucydides trap."

This, of course, does not contradict the growing importance of the digital factor in international relations. However, it implies that this 
process is of a reciprocal nature, or that the technological factor is still largely actualized by traditional (geo)political processes.

Technological war, which initially seemed to be a deviation, has become a new normal in the world's politics and economy.

The new digital revolution and rising competition for global hightech markets have increased their importance in the geopolitical conflict between the United States and China and, more broadly, in international relations. As a result, leadership is increasingly associated with the global redistribution of the "technological rent" and control of the digital markets as factors of [technological] sovereignty and structural power.

The origins of this process are rather subjective, but it will entail serious consequences for the world economy and politics. Elites and some experts see ICT through the lens of international risks and threats, sometimes even regarding digital services and corporations as weapons. As a consequence, digital development is perceived as a non-cooperative game, which explains many baffling aspects of the current U.S.-China digital conflict. In turn, attempts to apply traditional geopolitical instruments to high-tech markets lead to serious distortions in the normal mechanisms of their operation and, in the future, may even reduce the digital transformation potential. At the same time, technological conflicts aggravate the already severe international contradictions.

However, this process may not necessarily lead to Hobbesian technology wars of all against all, balkanization of markets, or a digital Cold War. Geopolitics of high tech will have to take into account the specifics of digital technologies and markets. In particular, the global nature of the ICT industry and the ongoing internationalization of Internet markets can become a natural obstacle to the emergence of blocs and to the sovereignization of the digital sphere. In other words, despite the seemingly complete picture of the Tech War with its quasibipolarity, this is merely an intermediate step towards a future state of both international relations and high-tech markets, with digital technologies possibly playing a new, more constructive role in global politics. 


\section{References}

Afontsev, S.A., 2020. Politika i ekonomika torgovykh voin [Politics and Economics of Trade Wars]. Journal of the New Economic Association, 1, pp. 193-198. DOI: 10.31737/2221-2264-2020-45-1-9.

Atkinson, R.D. and Ezell, S.J., 2012. Innovation Economics: The Race for Global Advantage. New Haven, Yale University Press.

Barnett, M., Duvall, R., 2005. Power in International Politics. International Organization, 59(1), pp. 39-75.

Brooks, S.G. and Wohlforth, W.C., 2016. The Once and Future Superpower. Foreign Affairs, May/June, pp. 91-104.

Brynjolfsson, E., McAfee, A., 2016. The Second Machine Age. N.Y.: W. W. Norton \& Company.

Cafruny, A., 2019. Can the United States Contain China? Russia in Global Affairs, 17(1), pp. 100-122. Available at: eng.globalaffairs.ru/articles/can-theunited-states-contain-china/ [Accessed 20 October 2021].

Capri, A., 2020. Techno-Nationalism: The US-China Tech Innovation Race. Hinrich Foundation [online]. Available at: https://research.hinrichfoundation. com/hubfs/White\%20Paper\%20PDFs/US-China\%20innovation\%20race $\% 20$ (Alex\%20Capri)/Hinrich\%20Foundation\%20-\%20Techno-nationalism\%20 and\%20the\%20US-China\%20tech\%20innovation\%20race\%20-\%20Alex\%20 Capri\%20-\%20August\%202020.pdf?_hsfp $=4168755785 \&$ _ hssc $=25165288$ 9.26.1608134071639\&_hstc $=251652889.767 \mathrm{e} 6 \mathrm{e} 5 \mathrm{e} 25787 \mathrm{f} 143553 \mathrm{~d} 911 \mathrm{ef} 16 \mathrm{a} 5$ be.1608134071638.1608134071638.1608134071638.1 [Accessed 30 July 2021].

Cartwright, M., 2020. Internationalizing State Power through the Internet: Google, Huawei and Geopolitical Struggle. Internet Policy Review, 9(3), pp.1-18. DOI: $10.14763 / 2020.3 .1494$.

Congressional Research Service, 2020. Semiconductors: U.S. Industry, Global Competition, and Federal Policy. CRS Report Prepared for the Members and Committees of Congress. R46581 [online]. Available at: crsreports.congress. gov/product/pdf/R/R46581?_cf_chl_jschl_tk__=pmd_wPiTeLsN2DtpWGL MmBvhH03fBS5jx0SkUVfqt2ksWXg-1634515534-0-gqNtZGzNAlCjcnBszRU9 [Accessed 30 September 2021].

Cory, N. and Atkinson, R.D., 2020. Why and How to Mount a Strong, Trilateral Response to China's Innovation Mercantilism. Information Technology \& Innovation Foundation [online]. Available at: itif.org/sites/default/files/2020trilateral-china.pdf [Accessed 30 July 2021]. 
Danilin, I.V., 2020. Amerikano-kitaiskaya tekhnologicheskaya voina: riski i vozmozhnosti dlya KNR i globalnogo tekhnologicheskogo sektora [The U.S.China Technology War: Risks and Opportunities for P.R.C. and Global Tech Sector]. Comparative Politics Russia, 11(4), pp.160-176. DOI: 10.24411/22213279-2020-10056.

Davis, B. and Wei, L., 2019. China's Plan for Tech Dominance Is Advancing, Business Groups Say. The Wall Street Journal, 22 January [online]. Available at: www.wsj.com/articles/u-s-business-groups-weigh-in-on-chinas-technologypush-11548153001 [Accessed 30 July 2021].

Ding, J. and Dafoe, A., 2021. The Logic of Strategic Assets: From Oil to AI. Security Studies, 30(2), pp. 182-212. DOI: 10.1080/09636412.2021.1915583.

Dorfman, Z., 2020. Tech Giants Are Giving China a Vital Edge in Espionage. Foreign Policy, 23 December [online]. Available at: foreignpolicy. com/2020/12/23/china-tech-giantsprocess- stolen-data-spy-agencies/ [Accessed 30 July 2021].

European Union, 2019. Expanding the EU's Digital Sovereignty. Official website of Germany's Presidency of the Council of the European Union, 27 October [online]. Available at: www.eu2020.de/eu2020-en/eu-digitalisation-technologysovereignty/2352828 [Accessed 30 July 2021].

Fidler, D.P., 2020. The Clean Network Program: Digital Age Echoes of the "Long Telegram"? Council on Foreign Relations, 5 October [online]. Available at: www.cfr.org/blog/clean-network-program-digital-age-echoes-long-telegram [Accessed 30 July 2021].

Gewirtz, J.B., 2019. China’s Long March to Technological Supremacy. Foreign Affairs, 27 August [online]. Available at: www.foreignaffairs.com/articles/ china/2019-08-27/chinas-long-march-technological-supremacy [Accessed 30 July 2021].

Grimes,S., Du, D., 2020. China's Emerging Role in the Global Semiconductor Value Chain. Telecommunications Policy. DOI: 10.1016/j.telpol.2020.101959

Gwynn, M.A., 2019. Structural Power and International Regimes. Journal of Political Power, 12(2), pp. 200-223. DOI: 10.1080/2158379X.2019.1618486.

Hansen, L. and Nissenbaum, H., 2009. Digital Disaster, Cyber Security, and the Copenhagen School. International Studies Quarterly, 53, pp. 1155-1175.

Hobbs, C. (ed.), 2020. Europe's Digital Sovereignty: From Rulemaker to Superpower in the Age of U.S.-China Rivalry. The European Council on Foreign 
Relations [online]. Available at: www.ecfr.eu/page/-/europe_digital_sovereignty_ rulemaker_superpower_age_us_china_rivalry.pdf [Accessed 30 July 2021].

Hufbauer, C.G. and Jung, E., 2020. What's New in Economic Sanctions? European Economic Review, 130. DOI: 10.1016/j.euroecorev.2020.103572.

Hufbauer, C.G., Schott, J., Elliott, K.A. and Oegg, B., 2008. Economic Sanctions Reconsidered. 3rd Edition. Washington, DC: Peterson Institute for International Economics.

Irwin, D.A., 1996. The U.S.-Japan Semiconductor Trade Conflict. In: A.O. Kruege (ed.). The Political Economy of Trade Protection. National Bureau of Economic Research [online]. Available at: www.nber.org/system/files/chapters/c8717/ c8717.pdf [Accessed 30 July 2021].

Ishihara, S., 1991. The Japan That Can Say No: Why Japan Will Be First Among Equals. New York: Simon \& Schuster.

Istomin, I.A., 2020. Mirazhi innovatsy: "vklad" tekhnologicheskogo progressa v voennuyu nestabilnost' [Innovation Delusions: The Role of Technological Progress in Military Instability]. MGIMO Review of International Relations, 13(6), pp. 7-52. DOI: 10.24833/2071-8160-2020-6-75-7-52.

Johnson-Freese, J. and Erickson, A.S., 2006. The Emerging China-EU Space Partnership: A Geotechnological Balancer. Space Policy, 22, pp. 12-22. DOI: 10.1016/j.spacepol.2005.11.001.

Kaempfer, W.H. and Lowenberg, A.D., 2007. The Political Economy of Economic Sanctions. In: T. Sandler and K. Hartley (eds.) Handbook of Defense Economics. Vol. 2. Amsterdam: Elsevier, pp. 867-911. DOI: 10.1016/S1574-0013(06)02027-8.

Khanin, G.I., 2008. Ekonomicheskaya istoriya Rossii v noveishee vremya [Economic History of Russia in Modern Times], Vol. 1. Novosibirsk: Novosibirsk state technical University.

Kim, M.-j., Heejin, L. and Jooyoung, K., 2020. The Changing Patterns of China's International Standardization in ICT under Techno-Nationalism: A Reflection through 5G Standardization. International Journal of Information Management, 54. DOI: 10.1016/j.ijinfomgt.2020.102145.

Kissinger, H., 2014. World Order. Penguin Books.

Lacy, M. 2018. Securitization and the Global Politics of Cybersecurity. Global Discourse, 8(1), pp. 100-115. DOI: 10.1080/23269995.2017.1415082. 
Lapedus, M., 2019. China Speeds Up Advanced Chip Development. Semiconductor Engineering, 22 June [online]. Available at: semiengineering. com/chinaspeeds-up-advanced-chip-development/ [Accessed 30 July 2021].

Laskai, L., 2018. Why Does Everyone Hate Made in China 2025? Council on Foreign Relations [online]. Available at: www.cfr.org/blog/why-does-everyonehate-made-china-2025 [Accessed 30 July 2021].

Leksyutina, Ja., 2020. Amerikano-kitajskiye otnosheniya v 2018-2019 gg.: torgovaya voina i process dekaplinga [U.S.-China Relations 2018-2019: Trade War and Decoupling Process]. Mirovaya ekonomika i mezhdunarodnye otnosheniya, 64(6), pp. 85-93. DOI: 10.20542/0131-2227-2020-64-6-85-93.

Manning, R.A. 2019. Techno-Nationalism vs. the Fourth Industrial Revolution. Global Asia, 14(1) [online]. Available at: www.globalasia.org/v14no1/cover/ techno-nationalism-vs-the-fourth-industrial-revolution_robert-a-manning [Accessed 30 July 2021].

Manuel, A. and Hicks, K. 2020. Can China's Military Win the Tech War? Foreign Affairs, 29 July [online]. Available at: www.foreignaffairs.com/articles/unitedstates/2020-07-29/can-chinas-military-win-tech-war [Accessed 30 November 2020].

Mascitelli, B. and Chung, M., 2019. Hue and Cry over Huawei: Cold War Tensions, Security Threats or Anti-Competitive Behavior? Research in Globalization, 1. DOI: 10.1016/j.resglo.2019.100002.

Mastanduno, M., 1985. Strategies of Economic Containment: U.S. Trade Relations with the Soviet Union. World Politics, 37(4), pp. 503-531.

Miller, C., 2019. A Semiconducted Trade War. Foreign Affairs [online]. Available at: foreignpolicy.com/2019/07/01/a-semiconducted-trade-war/ [Accessed 30 September 2021].

Morito, A., 2014. Sony. Sdelano v Yaponii [Sony. Made in Japan]. Moscow: Alpina.

Nakayama, S., 2012. Techno-Nationalism versus Techno-Globalism. East Asian Science. Technology and Society: An International Journal, 6(1), pp. 9-15. DOI: 10.1215/18752160-1504708.

National Science Board, 2020. Production and Trade of Knowledge- and Technology Intensive Industries. Science \& Engineering Indicators. NSB-2020-5 [online]. Available at: ncses.nsf.gov/pubs/nsb20205/global-trade-in-high-andmedium-high-r-d-intensive-products [Accessed 30 July 2021]. 
Oates, S., 2020. The Easy Weaponization of Social Media: Why Profit Has Trumped Security for U.S. Companies. Digital War, 1, pp. 117-122. DOI: 10.1057/s42984-020-00012-z.

OECD, 2020. OECD Digital Economy Outlook 2020. Paris: OECD Publishing.

Qin, J.Y., 2019. Forced Technology Transfer and the US-China Trade War: Implications for International Economic Law. Journal of International Economic Law, 22(4), pp. 743-762. DOI: 10.1093/jiel/jgz037.

Raska, M., 2021. The Sixth RMA Wave: Disruption in Military Affairs? Journal of Strategic Studies, 44(4), pp. 456-479. DOI: 10.1080/01402390.2020.1848818.

Riecke, T., 2020. Resilience and Decoupling in the Era of Great Power Competition. China Monitor, MERICS [online]. Available at: merics.org/sites/ default/files/2020-08/Merics_ChinaMonitor_PowerCompetition.pdf [Accessed 30 July 2021].

Rifkin, J., 2014. Zero Marginal Cost Society. New York, Palgrave MacMillan.

Rogov, M.I., 2016. Mezhdunarodnye ekonomicheskie sanktsii: analiz keisa s Rossiei v 2014 godu [International Economic Sanctions: An Anaalysis of the 2014 Russia Case]. Zhurnal Marketing MVA. Marketingovoye upravlenie predpriyatiem, 2, pp. 133-157.

Ross, A. 2011. Digital Diplomacy and US Foreign Policy. The Hague Journal of Diplomacy, 6(3-4), pp. 451-455. DOI: 10.1163/187119111X590556.

Salitsky, A. I. and Semenova, N. K., 2019. SShA-Kitai: anatomija torgovogo konflikta [USA-China: An Anatomy of the Trade Conflict]. Vostok-Oriens, 223(4), pp. 60-72. DOI: 10.31857/S086919080005960-3.

Schwab, K., 2017. The fourth industrial revolution. New York, Currency Books.

Segal, A., 2019. Seizing Core Technologies: China Responds to U.S. Technology Competition. China Leadership Monitor. The Washington International Trade Association (WITA) [online]. Available at: www.wita.org/nextgentrade/chinaresponds-u-s-tech-competition/ [Accessed 30 July 2021].

Semiconductor Industry Association, 2020. State of the U.S. Semiconductor Industry, 2020 [online]. Available at: www.semiconductors.org/wp-content/ uploads/2020/06/2020-SIA-State-of-the-Industry-Report.pdf Available at: [Accessed 30 September 2021].

Shen, H., 2018. Building a Digital Silk Road? Situating the Internet in China's Belt and Road Initiative. International Journal of Communication, 12, pp. 2683-2701. 
Shim, Y. and Shin, D.-H., 2016. Neo-Techno Nationalism: The Case of China's Handset Industry. Telecommunications Policy, 40(2-3), pp. 197-209. DOI: 10.1016/j.telpol.2015.09.006.

Simon, D.F. (ed), 1996. Techno-Security in an Age of Globalization: Perspectives from the Pacific Rim. New York: Routledge.

Smeets, M., 2018. Can Economic Sanctions Be Effective? World Trade Organization, WTO Staff Working Paper, No. ERSD-2018-03, Geneva [online]. Available at: www.econstor.eu/bitstream/10419/176768/1/1016551045.pdf [Accessed 30 July 2021].

Smith, N.R. and Brown, R.J., 2021. Neither a New Cold War nor a New Peloponnesian War: The Emerging Cyber-narrative Competition at the Heart of Sino-American Relations. Vestnik RUDN. International Relations, 21(2), pp. 252-264. DOI: 10.22363/2313-0660-2021-21-2-252-264

Steinbock, D., 2018. U.S.-China Trade War and Its Global Impacts. China Quarterly of International Strategic Studies, 4(4), pp. 515-542. DOI: 10.1142/ S2377740018500318.

Sun, H., 2019. U.S.-China Tech War: Impacts and Prospects. China Quarterly of International Strategic Studies, 5(2), pp. 197-212. DOI: 10.1142/ S237774001950012X.

TASS, 2017. Putin Stresses He Who Takes the Lead in Artificial Intelligence Will Rule the World. TASS, 1 September [online]. Available at: tass.com/ society/963209 [Accessed 30 September 2021].

The World Bank, 2021. ICT Goods Exports (\% of Total Goods Exports) [online]. Available at: data.worldbank.org/indicator/TX.VAL.ICTG.ZS.UN. [Accessed 30 July 2021].

Triolo, P. 2020. The Telecommunications Industry In U.S.-China Context. National Security Report. The Johns Hopkins University Applied Physics Laboratory [online]. Available at: www.jhuapl.edu/Content/documents/TrioloTelecomms.pdf [Accessed 30 July 2021].

U.S. Congress, 2019. Made in China 2025 and the Future of American Industry. Hearing Before the Committee on Small Business and Entrepreneurship. United States Senate. 116th Congress. 1st Session. 27 February. Wash.: U.S. Government Publishing Office.

U.S. Department of Defense, 2020. Military and Security Developments Involving the People's Republic of China 2020. Annual Report to Congress [online]. 
Available at: media.defense.gov/2020/Sep/01/2002488689/-1/-1/1/2020-DODChina-MILITARY-POWER-REPORT-FINAL.PDF [Accessed 30 September 2021].

U.S. Department of State, 2020. The Elements of China Challenge. Office of the Secretary of State [online]. Available at: www.state.gov/wp-content/ uploads/2020/11/20-02832-Elements-of-China-Challenge-508.pdf [Accessed 30 September 2021].

UNCTAD, 2019. Digital Economy Report 2019. The United Nations Conference on Trade and Development. New York: United Nations Publications.

UNCTAD, 2021. Bilateral Trade Flows by ICT Goods Categories, Annual [online]. Available at: unctadstat.unctad.org/wds/TableViewer/tableView. aspx?ReportId=15850 [Accessed 30 September 2021].

Vogel, S.K., 1989. Japanese High Technology, Politics, and Power. Berkeley Roundtable on the International Economy. Research Paper \#2. University of California, Berkeley [online]. Available at: ageconsearch.umn.edu/ record/292939/files/ucb-0002.PDF [Accessed 30 July 2021].

Wei, L., 2019. Beijing Drops Contentious 'Made in China 2025' Slogan, but Policy Remains. The Wall Street Journal, 5 March [online]. Available at: www.wsj.com/articles/china-drops-a-policy-the-u-s-dislikes-at-least-inname-11551795370 [Accessed 30 July 2021].

Wu, X., 2020. Technology, Power, and Uncontrolled Great Power Strategic Competition between China and the United States. China International Strategy Review, 2, pp. 99-119. Available at: doi.org/10.1007/s42533-020-00040-0 [Accessed 20 October 2021]. 